pressure should produce greater benefits, but this has not been studied in randomised trials. It has been suggested that lowering diastolic blood pressure below $90 \mathrm{~mm} \mathrm{Hg}$ in patients with coronary heart disease may have adverse effects. ${ }^{10}$ Randomised trials of $\beta$ blockers and angiotensin converting enzyme inhibitors in patients with coronary heart disease do not support the existence of such adverse effects. ${ }^{11} 12$

- Once their blood pressure is stabilised most patients require only six monthly follow up.

The report was commissioned by the National Advisory Committee on Core Health and Disability Support Services. This committee is charged with advising the minister of health on what health services the government should purchase for the New Zealand population.

1 Kawachi I, Wilson $\mathrm{N}$. The evolution of antihypertensive treatment. Soc $S c$ Med 1990;31:1239-43.

2 MacMahon S, Peto R, Cutler J, Collins R, Sorlie P, Neaton J, et al. Blood pressure, stroke and coronary heart disease. Part 1. Prolonged differences in blood pressure: prospective observational studies corrected for regression dilution bias. Lancet 1990;335:765-74.

3 Anderson $\mathrm{KM}$, Wilson PWF, Odell PW, Kannel WB. An updated coronary risk profile. A statement for health professionals. Circulation 1991;83:356-

4 Joint National Committee. The 1988 report of the Joint National Committec on Detection, Evaluation and Treatment of High Blood Pressure. Arch Intern Med 1988:148:1023-38.

5 Guidelines Sub-Committee 1989 Guidelines for the management of mild hypertension: memorandum from a WHO/ISH meeting. I Hyperten hypertension:

6 British Hypertension Working Party. Treating mild hypertension. $B M \nearrow$ 1989;298:694-8

7 Collins R, Peto R, MacMahon S, Herbert P, Fiechbach NH, Eberein KA et al. Blood pressure, stroke, and coronary heart disease. Part 2. Short-term reductions in blood pressure: overview of randomised drug trials. Lancet 1990;335:827-38

8 Russel D, Wilson N. Life in New Zealand survey commission report. Executive overview. Dunedin: University of Otago, 1991.

9 Carlsen JE, Kober L, Torp-Pendersen C, Johansen P. Relationship between dose of bendrofluazide, antihypertensive effect, and adverse biochemical effects. BMY 1990;300:975-8.

10 Cruikshank JM, Thorp JM, Zacharias FJ. Benefits and potential harm of lowering high blood pressure. Lancet 1987; ;:581-4.

11 BBPP Research Group. The Beta-Blocker Pooling Project (BBPP): subgroup findings from randomized trials in post infarct patients. Eur Heart $f$ 1988;9:8-16.

12 Pfeffer MA, Braunwald E, Lemuel AM, Basta L, Brown EJ, Cuddy TE, et al. Effect of captopril on mortality and morbidity in patients with left ventricular dysfunction after myocardial infarction. Results of the surviva and ventricular enlargement study. N Engl f Med 1992;327:669-77.

(Accepted 24 April 1993)

\title{
Health professionals and South Africa: supporting change in the health sector
}

\author{
Tony Waterston, Anthony Zwi
}

Now that political change is on the way in South Africa, what should be the position of doctors who are invited to visit the country? Does the "academic boycott" still have relevance? Waterston and Zwi review the case for and against an academic boycott policy, using evidence collected during the recent visit by Physicians for Human Rights (UK) and the Johannes Wier Foundation. The health system in South Africa is still inequitable, and despite progress towards desegregation in hospitals there is little momentum towards universal provision of primary health care, especially in the rapidly growing townships around big cities. The authors consider that pressure on the government should be maintained by outside organisations but that support directed towards appropriate health care should be encouraged, particularly in public health and primary health care.

\section{Background}

The publication of the report of the Physicians for Human Rights (UK) and Johannes Wier Foundation on apartheid and health care ${ }^{1}$ provides an opportunity to review policy in relation to the boycott of South African health services and related institutions.

The boycott, nominally known as the "academic boycott" but extending beyond academics and their institutions, was introduced at the request of the African National Congress and was supported by its allies, both in South Africa and abroad. The African National Congress considered it necessary to institute a set of measures to isolate South Africa in the economic, military, cultural, sporting, and academic spheres of life. It was argued that this would increase pressure for change from business as well as from sports enthusiasts and academics by making it clear that apartheid was totally unacceptable to the world community and that the penalties for maintaining the status quo would increase. At the same time, trade and military sanctions would weaken the ability of the state to repress opposition within the country and to destabilise the surrounding states. The African National Congress argued that no part of society should be spared by the boycott.

In the health sector, apartheid ensured the inequitable distribution and quality of health care between black and white, urban and rural, wealthy and poor. The training of medical and allied health personnel was deeply divided: medical schools were largely segregated by race, with even the more liberal schools including only a minority of black students and having even fewer blacks on their staff. Furthermore, the establishment medical bodies, such as the Medical Association of South Africa and the South African Medical and Dental Council, played deeply divisive roles by not challenging the impact of apartheid in health and even giving tacit support to doctors who explicitly abused their ethical responsibilities, such as the doctors involved in the case of Stephen Biko. ${ }^{3}$

A policy of isolation was seen as the mechanism whereby overseas doctors could make clear their absolute abhorrence of apartheid. It would also encourage health professionals in South Africa to challenge apartheid and make the state realise that only fundamental change would allow their acceptance into the world community. Any benefits from international medical exchange would be far outweighed by progress towards ending apartheid.

Opponents of the African National Congress's stance took the view that the medical ethic of internationalism, the free exchange of knowledge, and the commitment of care for patients from all backgrounds takes precedence over political campaigning. It was argued that the strategy may be counterproductive and lead to acceptance of the status quo. ${ }^{4}$ Despite this widely canvassed view many medical organisations in the United Kingdom, including the British Medical Association, supported the boycott: the BMA withdrew from the World Medical Association because of its refusal to expel South Africa. Nevertheless, some doctors and medical students continued to travel to South Africa and its bantustans for training and experience. 
In January 1989 a modified version of the academic boycott in the health sector was proposed by the National Medical and Dental Association, a progressive organisation of doctors and dentists opposed to apartheid and striving for a just and democratic South Africa conducive to health for all. "Selective support" was proposed in order to encourage academic exchange that accorded with certain aims and principles: the individual should be invited or supported by an organisation or institution with a record of active and committed opposition to apartheid and of working for a non-racial, democratic, and unitary South Africa; he or she should be willing to make a public statement indicating opposition to apartheid; and interviews with the government-controlled state media were to be avoided. ${ }^{5}$ The African National Congress endorsed the concept of supporting health professionals and organisations actively committed to the eradication of apartheid. ${ }^{\circ}$

\section{The team's findings}

The Physicians for Human Rights and Johannes Wier Foundation team visited academic centres in Johannesburg, Cape Province, and Durban and interviewed a spectrum of medical faculty members. The majority view was that academic work had been constrained by the boycott, which had restricted research capacity, ability to keep up to date with medical advances, and postgraduate teaching programmes. Most disputed that the boycott had affected government policy. However, the team noted that progressive health organisations are critical of the lack of involvement of many academics in the reform process. There seems to be little evidence of affirmative action in medical schools to enhance the opportunities for black students: medical teaching is still biased towards hospital care and cure rather than community care and prevention, and academic staff provide inadequate support for primary health care (with the exception of several departments of paediatrics, community health, and family medicine).

There seems little doubt, however, that the boycott strategy generally added to the pressure for reforms to the apartheid state. Professional groups and universities more readily condemned apartheid and its impact on health-it became almost ritual for statements of intent by medical schools to begin with an affirmation of equity. Doctors have opposed detention without trial, have proposed a system of access to independent medical practitioners for detainees, and developed ethical guidelines for treating hunger strikers. The main medical organisation, MASA (the Medical Association of South Africa), which was formerly a supporter of the status quo, has become much more active in condemning discrimination and arguing for equity of access to health care. Similarly the South African Medical fournal, which in the past had a record of refusing articles critical of the medical profession, has opened its columns to all views, and recently has condemned its own past policy in a leading article. $^{7}$

Some medical schools are moving towards a more balanced admissions policy and more appropriate medical education. For example, in Cape Town an additional 20 black students are now selected each year on lower criteria and are allowed an extra year for the first three years of the course. However, this programme is itself criticised for being paternalistic as it did not acknowledge the damaging effects of being educated in inferior schools.

A negative effect of the boycott on the medical profession may have been to encourage outward migration by doctors. The investigating team did not collect evidence on this, but it should be recognised that medical emigration is a common problem in many developing countries.

In May 1990 the minister of health indicated that apartheid should be removed in access to hospital care. The team found that progress towards this goal is slow. Several of the hospitals it visited are still segregated, supposedly because the local population is conservative and would oppose too rapid reforms. Private hospitals in the same areas have, however, removed racial barriers without eliciting any protests.

The team found that the health sector remains deeply fragmented owing to the historical legacy of the tricameral parliamentary system and a regional structure that supports 14 separate departments of health (one for each of the 10 homelands, one for each of the "non-African" racial groups, and one national department). There is also a deep fragmentation between preventive and (hospital) curative services. Access to health care is racially and economically biased, and primary health care receives low priority, despite rhetoric to the contrary.

\section{Recommendations}

What then, should be the current attitude of the international health community, given the legalisation of the African National Congress and the removal of some of the worst manifestations of apartheid?

There should be recognition that a new government will be beset by economic difficulties that will make it hard to implement redistributive policies. Other countries have experience of such a situation and their assistance should be specifically sought. In the first place, pressure on the South African state should be maintained. Outside support for a rapid transition to an elected government and an end to political violence are essential. Pressure needs to be kept up so that reforms within the health sector are followed through: broader access to services is required, inequalities in funding need to be removed, accountability of service providers to their clientele needs to be assured, quality of care needs to be enhanced, fragmentation of services needs to end. There are no precise formulas for overcoming these obstacles, but they need to be kept high on the agenda and openly debated if the pace of change is not to falter.

Secondly, anyone considering travelling to South Africa should carefully evaluate the role they can and do play. Visitors to the country should recognise that their interest may be interpreted as supporting the status quo, including the current highly skewed distribution of health services, unless they make quite clear their opposition to such maldistribution. Their involvement, however well intentioned, with particular individuals and institutions that do not have a record of challenging the impact of apartheid on health, may be interpreted as tacit support for those opposed to progressive change.

The African National Congress has in fact called for an end to person to person sanctions, implying that academic contact could be encouraged. But it is the nature of contact that is important: there is a clear need for skilled personnel and for the experience and insights of those who have worked within other health systems and in other economic and sociopolitical contexts. South Africans, like all of us, have much to learn from colleagues in Africa and further afield.

Where possible, the support offered should remain designed to promote change: improving equity, enhancing the quality of services, facilitating increased access to services, encouraging a critical examination of the existing structure. Support should be given to those in the country who are working to develop appropriate health services for the future South Africa. Certain contributions will be especially valuable at the 
present time and should feed into the ongoing debates about health sector restructuring-namely, public health and policy including health economics, epidemiology, health systems research, primary health care development, education and training of health personnel, health promotion, and health services management. A strong public health influence on health sector planning will be necessary, as will be the development of a cadre of skilled health service managers-both totally lacking in South Africa today. Clinical expertise, too, is of extreme value, but it needs to be proffered in the context of improving appropriate levels of care, with an eye kept on cost effectiveness and enhancing quality.

Lastly, individuals travelling to South Africa should make it their objective to learn about what is happening in the country. Whether they are invited to attend a conference or to practise in the health care services, they should make a point of finding out about the population served by that service. Who has access? Where do the people come from? How much do they pay? What service is available to them at home?

Individuals should seek to visit the more peripheral areas and get out of the urban centres, big hospitals, and plush surroundings in order to see something of the real problems facing the vast majority of South Africans. For most people, life is what it always has been: much more radical change is required before their lot will be improved. Visitors should be cognisant of the real challenge facing health workers in South Africa: transforming the sociopolitical and economic environment into one that is health promoting, and devising a health service that is equitable, of high quality, accessible, and available to all.

1 Physicians for Human Rights and Johannes Wier Foundation. South Africa 1991. Apartheid and Health care in transition-a report on progress, impediments and means of support. Dundee, Physicians for Human Rights 1992. (Obtainable from PHR (UK), clo University Department of Forensic Medicine, able from PHR (UK), co University Depart

2 Kaiser Family Foundation. Changing health in South Africa: towards new perspectives in research. Menlo Park, California: Kaiser Family Foundation, 199

3 Silove D. Doctors and the state: lessons from the Biko case. Soc Sci Med 1990;30:417-29.

4 Benatar SR. The moral validity of medical practice in South Africa and the challenges for the future. $S$ Afr Med $\mathcal{O} 1989 ; 75: 362-4$.

5 National Medical and Dental Association. NAMDA and the academic boycott of South Africa. Durban: NAMDA, 1989. (Special bulletin 2.)

6 National Medical and Dental Association. NAMDA-ANC meeting, 21-22 October 1989. Durban: NAMDA, 1990. (Sepecial bulletin 3.)

7 Lee NC. The right to speak-Biko revisited. S Afr Med f 1991;79:635-7.

\section{Letter from Kosovo}

\section{Coping with Serbian repression in an Albanian population}

\section{Lynne Jones}

It looks like an ordinary suburban villa-neat; white, two storeys with a garage. In the garden there are fruit trees coming into bloom and green spikes show through the freshly turned earth of the vegetable patch. The garage door is open. Inside, however, instead of a car or the detritus of household goods, are fresh painted walls, noticeboards covered with class lists and timetables, and clusters of young people examining them. These are the offices of the "parallel" Prishtina medical school in Kosovo. The school was established by Albanian staff and their students after Serbian authorities dismissed most of the Albanian medical faculty from the official medical school and ended university teaching in Albanian in late 1990.

Around the corner in an abandoned grocery shop, under dusty adverts for soft drinks, are some wooden benches and a few microscopes that make up the histology laboratory. In the basement of another villa students prepare for an exam in infectious diseases. According to Dr Alush Gashi, sacked dean of the official medical school, some 2000 Kosovo Albanian students study in this way-"Of course, it is far from ideal, but the theoretical teaching is of a very high standard." Clinical teaching is done in the "parallel" outpatient clinics, run from the homes of some of the sacked physicians. Exams are much more rigorous than before, and the plan is that after qualification students should work as assistant physicians for two years.

\section{Edinburgh EH9 2LD Lynne Jones, psychiatrist and writer}

Correspondence to:

8 Grange Terrace,

Edinburgh EH9 2LD.

$B M \Im$ 1993;307:112-4

\section{Recent educational and social conditions}

It was not always like this. Kosovo, the southernmost province of Serbia, has a population of just over 2 million, of whom roughly $90 \%$ are Albanian. The remainder are Serbian, with some other minorities. There has been a university medical school in Prishtina since 1969. Until 1990 medical students could study in their own language-Albanian or Serbian-except in those subjects in which Albanian language professors were unavailable, in which case all studied in Serbian. Clinical work, including written notes, was conducted in the language of the patient and doctor, mostly Albanian. However, summaries were written in Serbian, as were any notes needed for communication with doctors, hospitals, or laboratories in other areas. If any Serbian doctor attended a clinical meeting or seminar the meeting would automatically be conducted in Serbian, as most Serbian doctors did not speak Albanian. According to Albanian and Serbian doctors to whom I talked, relations were good. Dr Ferid Agani, a young psychiatrist, explained: "nations were not important-only one's professional skill."

Kosovo has specific health problems. With only $42 \%$ of the population living in buildings with a water supply and only $28 \%$ in buildings connected to the sewerage system there is a high incidence of infectious diseases. Kosovo also has the highest birth rate in Europe-29.5\%. ${ }^{1}$ The Serbian authorities argue that this "biological surplus... is the result of the planned increase in progenies, as a form of struggle... [and] civilisational backwardness." 2 Dr Drita Mekuli, however, points out that infant mortality is $49 \%$, which she believes stems from poor economic and social conditions encouraged by the discriminatory policies of Belgrade in the past 10 years. ${ }^{1}$ Albanians claim that it was these poor conditions that resulted in some Serbians leaving Kosovo during this period.

\section{Brutal measures}

Serbians allege that Albanians abused the autonomy granted the province by the 1974 constitution. This had made both Kosovo and the northern province of Vojvodina constituent members of the Yugoslav federation with their own parliaments and almost identical rights with the other sovereign republics. Serbians, however, believed this constitution gave 